\title{
First aid at school: teacher and staff training
}

\author{
Primeiros socorros na escola: treinamento de professores e funcionários
}

Lucas Felix Calandrim ${ }^{1}$, Adriana Breves dos Santos ${ }^{1}$, Lais Rodrigues de Oliveiraa ${ }^{1}$, Luciana Gonçalves Massaro ${ }^{1}$, Cleuza Aparecida Vedovato ${ }^{1}$, Ana Paula Boaventura ${ }^{1}$

Objective: to evaluate the knowledge of teachers and employees after first aid training. Methods: this is a near pretest and post-test experiment for 35 staff and teachers of a school, evaluated using validated instruments for knowledge and skill in two stages, before and after a course/training. Results: 97.1\% (34) female professionals participated, 42.8\% (15) reported having received some training and 71.4\% (25) had already witnessed an emergency case. Before the training, an average score of 19.43 referring to skill and 2.91 points in knowledge was verified and after 174.57 points in skill and 9.17 in knowledge, a statistically significant difference by the Wilcoxon Signal Station Test $(\mathrm{p}<0.001)$. Conclusion: training is effective, with a significant increase in the percentage of correct answers after first aid training in the school environment.

Descriptors: First Aid; Emergencies; School Health; Health Education; Health Promotion.

Objetivo: avaliar o conhecimento de professores e funcionários após um treinamento de primeiros socorros. Métodos: trata-se de um quase experimento do tipo pré e pós-teste, para 35 funcionários e professores de uma escola, avaliados com a utilização de instrumentos validados, quanto ao conhecimento e a habilidade em duas etapas, antes e após um curso/treinamento. Resultados: participaram 97,1\% (34) profissionais do sexo feminino, 42,8\% (15) afirmaram já terem recebido algum treinamento e 71,4\% (25) já presenciaram uma emergência. Verificou-se antes do treinamento uma pontuação média de 19,43 pontos referentes a habilidade e 2,91 pontos no conhecimento e após 174,57 pontos na habilidade e 9,17 no conhecimento, diferença estatisticamente significativa pelo Teste de Postos Sinalizados de Wilcoxon $(\mathrm{p}<0,001)$. Conclusão: $o$ treinamento é efetivo, com aumento significativo da porcentagem de acertos após o treinamento em primeiros socorros no ambiente escolar.

Descritores: Primeiros Socorros; Emergências; Saúde Escolar; Educação em Saúde; Promoção da Saúde.

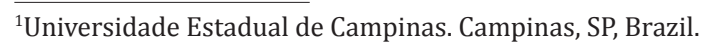




\section{Introduction}

Professionals working in the school environment, whether they are teachers or employees, should receive formal and ongoing training to deal with emergencies in the school environment, since school children and adolescents are more vulnerable to emergency situations due to developmental, physical and behavioral characteristics, including narrower airways, lower body mass and thinner skin, more susceptible to injuries ${ }^{(1-2)}$.

Children and adolescents spend most of their day at school today, where they are liable to suffer accidental injuries due to the large number of group activities. Recently, both the American Academy of Pediatrics and the American Heart Association have followed global guidelines for Cardiovascular Emergencies and Cardiorespiratory Resuscitation established by the International Liaison Committee on Resuscitation, which is being recommended by the World Health Organization for the purpose of emphasizing the need for trained professionals to establish plans for systemized emergencies in schools, as well as to deal with life-threatening and medical emergencies in children, since children and professionals are multipliers of knowledge and guaranteeing more effective assistance ${ }^{(3-6)}$.

Thus, some questions that guide this work refer to the teaching-learning process of first aid for adults, which encompasses techniques of psychomotor predominance involving a series of basic skills and abilities that need to be developed through training and the following questions arise: which are these capabilities and skills necessary for these individuals to be able to institute first aid maneuvers quickly and correctly in the face of a situation of emergency? How to adequately qualify and train teachers and staff to attend these emergencies?

The theoretical-conceptual bases that will be addressed involve teaching, learning and motor learning concepts involving the skills and abilities necessary to perform the first aid maneuvers ${ }^{(6-8)}$.
Thus, this study will evaluate the learning process of first aid maneuvers, which is a change in the person's ability to perform a skill, which should be inferred as a relatively permanent improvement in performance due to practice or experience. In the activities present in this first aid course there is a predominance of practices for the application of acquired knowledge and habilitation of the maneuvers ${ }^{(6-8)}$.

First-aid techniques involve complex maneuvers with a predominance of the motor domain. In order to better understand the teaching-learning process involving these maneuvers; it is necessary to understand the development of these maneuvers, both in the cognitive and motor areas ${ }^{(7-8)}$.

Changes in motor behavior mean improving skills to solve problems that involve responses close to the patterns of movement practiced. The moment of practice is a moment of learning, since it reinforces acquired skills and it is possible to apply them in new situations $^{(7-8)}$.

Considering the above, this study is justified by the importance of the broad training of all the professionals who work in the school environment, in the approach to the basic notions of first aid as well as the implementation of emergency care plans in these environments, the objective of this study is to evaluate the teachers' and employees' knowledge about first aid training.

\section{Methods}

This is a near pretest and post-test experiment carried out at a school in the interior of the State of São Paulo, Brazil, which works with grade and high school education, with approximately 600 students enrolled and about 40 employees and teachers.

The samples consisted of 35 professionals, six employees and 29 teachers from the school who agreed to participate in the study and were able to attend the data collection stages. These were assembled in groups previously scheduled and participated in the course on first aid given by the researchers. 
The course lasted approximately two hours, in which the following theoretical and practical contents were presented: recognition of the emergency situation, basic maneuvers of cardiopulmonary resuscitation as follows: assess level of consciousness, request help by triggering the emergency medical service (192/193), make chest compressions, use of external defibrillator automatic; recognition of the choked victim, use of disengagement maneuvers in adults and children, as well as conduct in situations such as: external hemorrhage, seizure, fainting, nasal bleeding and dental avulsion; and also in which situations should trigger the rescue.

The teaching strategy used was to approach the theoretical aspects with immediate practical demonstration of all maneuversin simulating manikins, adult and pediatric puppets for cardiopulmonary resuscitation and automatic external defibrillator for training, all participants performed the practical training of the maneuvers until the correct execution of the maneuvers.

Two instruments were used to collect data, one for the evaluation of the ability (practice) and another for the evaluation of knowledge (theoretical), were adapted by the researcher according to the global guidelines for Cardiovascular Emergencies and Cardiorespiratory Resuscitation prepared by the International Liaison Committee on Resuscitation 2015 -2020 and other similar studies ${ }^{(6-7,9-11)}$.

For the evaluation of the skill, a check list with 19 items was used, being a score attributed to each item with maximum total score to be obtained of 180 points.

To evaluate the knowledge an instrument with 10 objective questions was used and each question evaluated a specific content in first aid with total score to be obtained of 10 points.

Data were collected in two stages. In the first step both instruments of data collection were applied in order to evaluate the knowledge and the initial ability of the participants. On the same day, a theoretical- -practical course was given on simulated mannequins and simulated scenarios of emergency care.

In the second stage, immediately after the course/training, both instruments of data collection were again applied for the evaluation of the participants' knowledge and final ability.

The data collected were inserted in a spreadsheet (Microsoft Excel ${ }^{\circ}$ ) and analyzed statistically. For the comparisons between the two moments of evaluation, in each of the groups, the Wilcoxon benchmark test was applied to the scores. This test is applied when the objective is to compare two dependent samples $^{(12)}$.

Once comparisons were made between the before and after scores, the level of significance assumed was 5\%. Statistical Analysis Software version 9.4 and Statistical Package for the Social Sciences version 22 were used for the analysis.

The study complied with the formal requirements contained in national and international standards for research involving human beings.

\section{Results}

Participants were professionals aged between 17 and 49 years, $97.1 \%$ (34) were female, $42.8 \%$ (15) said they had received some previous training and $71.4 \%$ (25) said they had already witnessed some situation of emergency.

Before the training, an average score of 19.43 points for the skill and an average of 2.91 points for the knowledge were verified. After the training the average in the skill was of 174.57 points and in the knowledge 9.17 points.

In all the compared data before and after there was a statistically significant difference $(\mathrm{p}<0.001)$.

For better presentation of the results the evaluation of the contents was divided into three groups: 1- Identification and call for help; 2Cardiopulmonary resuscitation maneuver; 3- Use of the automatic external defibrillator shown in the tables that follow in the text. 
In the contents 1- "Identification and call help" the items and questions are presented in table 1, being possible to observe that the average percentage of correctness of these abilities was of $20.0 \%$ before the training and of $94.3 \%$ after.

Items one and two that correspond to "stimulating the victim, by touching the shoulders lightly", and "calling out loud are you okay?" are highlighted, respectively, who scored $100.0 \%$ after training. Ite$\mathrm{ms}$ three and four correspond to "Ask for help, call 192/193" and "Ask the External Automated Defibrillator", with a score of $88.6 \%$ after training $(\mathrm{p}<0.001)$.

Knowledge assessment (theoretical) obtained a statistically significant average of $37.9 \%$ before training and $91.4 \%$ after training $(\mathrm{p}<0.001)$.

Table 1 - Distribution of correct and incorrect items in the evaluation of the skills and knowledge of Content 1 - Identification and Call Help

\begin{tabular}{lcccc}
\hline & \multicolumn{2}{c}{ Before } & \multicolumn{2}{c}{ After } \\
\cline { 2 - 5 } Variable & Incorrect & Correct & Incorrect & Correct \\
& $\mathbf{n}(\%)$ & $\mathbf{n}(\%)$ & $\mathbf{n}(\%)$ & $\mathbf{n}(\%)$ \\
\hline Practice & & & & \\
1 & $29(82.9)$ & $6(17.1)$ & - & $35(100.0)<0.001$ \\
2 & $21(60.0)$ & $14(40.0)$ & - & $35(100.0)<0.001$ \\
3 & $27(77.1)$ & $8(22.9)$ & $4(11.4)$ & $31(88.6)<0.001$ \\
4 & $35(100.0)$ & - & $4(11.4)$ & $31(88.6)<0.001$ \\
Average & $28(80.0)$ & $7(20.0)$ & $2(5.7)$ & $33(94.3)<0.001$ \\
Theoretical & & & & \\
1 & $22(62.9)$ & $13(37.1)$ & $3(8.6)$ & $32(91.4)<0.001$ \\
2 & $21(60.0)$ & $14(40.0)$ & $5(14.3)$ & $30(85.7)<0.001$ \\
3 & $22(62.9)$ & $13(37.1)$ & $2(5.7)$ & $33(94.3)<0.001$ \\
4 & $22(62.9)$ & $13(37.1)$ & $3(8.6)$ & $32(91.4)<0.001$ \\
Average & $21.75(62.1)$ & $13.25(37.9)$ & $3(8.6)$ & $32(91.4)<0.001$ \\
\hline & & & &
\end{tabular}

Table 2 refers to the contents of the cardiopulmonary resuscitation maneuver, with an emphasis on chest compressions, in which the average ability score was $16.4 \%$ before the training of the professionals and $100.0 \%$ in all the items evaluated after the course. In the knowledge, the average of hits before was $20.0 \%$ and after training was $89.5 \%(\mathrm{p}<0.001)$.

We highlight items six and eight, which correspond respectively to "Kneeling next to the shoulder of the victim keeping the legs apart" and "Positioning the hands superimposed and interlaced to initiate chest compressions", for obtaining a $100.0 \%$ error in the evaluation before training, and $100.0 \%$ of hits after training.

Items five and seven were "Undressing the victim's thorax" and "Finding the point of compression in the center of the chest between the nipples", respectively, presented the highest percentage of hits (34.3\% and $42.9 \%)$ in the assessment of the skills before training.

Regarding the theoretical knowledge after the training, there was an increase in the percentage of correct answers in all the questions that evaluated the maneuvers of cardiopulmonary resuscitation.

Table 2 - Distribution of correct and incorrect items in the evaluation of the skills and knowledge of the Content 2 - Cardiopulmonary resuscitation maneuver

\begin{tabular}{lccccc}
\hline & \multicolumn{2}{c}{ Before } & \multicolumn{2}{c}{ After } \\
\cline { 2 - 5 } Variable & Incorrect & Correct & Incorrect & Correct & p \\
& $\mathbf{n ~ ( \% )}$ & $\mathbf{n}(\%)$ & $\mathbf{n}(\%)$ & $\mathbf{n}(\%)$ & \\
\hline Practice & & & & & \\
5 & $23(65.7)$ & $12(34.3)$ & - & $35(100.0)<0.001$ \\
6 & $35(100.0)$ & - & - & $35(100.0)<0.001$ \\
7 & $20(57.1)$ & $15(42.9)$ & - & $35(100.0)<0.001$ \\
8 & $35(100.0)$ & - & - & $35(100.0)<0.001$ \\
9 & $30(85.7)$ & $5(14.3)$ & - & $35(100.0)<0.001$ \\
10 & $32(91.4)$ & $3(8.6)$ & - & $35(100.0)<0.001$ \\
11 & $27(77.1)$ & $8(22.9)$ & - & $35(100.0)<0.001$ \\
12 & $32(91.4)$ & $3(8.6)$ & - & $35(100.0)<0.001$ \\
Average & $29.25(83.6)$ & $5.75(16.4)$ & - & $35(100.0)<0.001$
\end{tabular}

\section{Theoretical}

\begin{tabular}{lcccrc}
6 & $22(62.9)$ & $13(37.1)$ & $1(2.9)$ & $34(97.1)$ & $<0.001$ \\
7 & $34(97.1)$ & $1(2.9)$ & $7(20.0)$ & $28(80.0)$ & $<0.001$ \\
Average & $28(80.0)$ & $7(20.0)$ & $3.67(10.8) 31.33(89.5)<0.001$ \\
\hline
\end{tabular}


In Table 3, the items evaluated for the use of the automatic external defibrillator were described and it was verified that before the training there was $100.0 \%$ of error in the evaluation of these abilities that improved to $95.5 \%$ of correct answers after the training.

In the theoretical knowledge of these contents, there were $25.0 \%$ of correct answers before the training, rising to $94.3 \%$ after.

Table 3 - Distribution of correct and incorrect items in the evaluation of the skills and knowledge of the Content 3 - Use of automatic external defibrillator

\begin{tabular}{|c|c|c|c|c|c|}
\hline \multirow[b]{2}{*}{ Variable } & \multicolumn{2}{|c|}{ Before } & \multicolumn{2}{|c|}{ After } & \\
\hline & $\begin{array}{c}\text { Incorrect } \\
\text { n (\%) }\end{array}$ & $\begin{array}{c}\text { Correct } \\
\text { n (\%) }\end{array}$ & $\begin{array}{c}\text { Incorrect } \\
\text { n (\%) }\end{array}$ & $\begin{array}{l}\text { Correct } \\
\text { n (\%) }\end{array}$ & $\mathbf{p}$ \\
\hline
\end{tabular}

\section{Practice}

$\begin{array}{lllccc}13 & 35(100.0) & - & - & 35(100.0) & <0.001 \\ 14 & 35(100.0) & - & - & 35(100.0)<0.001 \\ 15 & 35(100.0) & - & - & 35(100.0) & <0.001 \\ 16 & 35(100.0) & - & 3(8.6) & 32(91.4)<0.001 \\ 17 & 35(100.0) & - & 3(8.6) & 32(91.4)<0.001 \\ 18 & 35(100.0) & - & - & 35(100.0)<0.001 \\ 19 & 35(100.0) & - & 5(14.3) & 30(85.7)<0.001 \\ \text { Average } & 35(100.0) & - & 1.58(4.5) 33.42(95.5)<0.001\end{array}$

Theoretical

\begin{tabular}{lccccc}
5 & $20(57.1)$ & $15(42.9)$ & $3(8.6)$ & $32(91.4)$ & $<0.001$ \\
8 & $23(65.7)$ & $12(34.3)$ & $1(2.9)$ & $34(97.1)$ & $<0.001$ \\
9 & $27(77.1)$ & $8(22.9)$ & - & $35(100.0)$ & $<0.001$ \\
10 & $35(100.0)$ & - & $4(11.4)$ & $31(88.6)$ & $<0.001$ \\
Average & $26.25(75.0)$ & $8.75(25.0)$ & $2(5.7)$ & $33(94.3)$ & $<0.001$ \\
\hline
\end{tabular}

\section{Discussion}

The limitations of this study refer to the availability of time and place in the school year so that teachers and staff can participate annually in formal courses and specific practical training in first aid in the school environment, so it is recommended that these activities are programmed annually in the scho- ol calendar and are integrated into the pedagogical contents worked in these schools.

Training in emergencies in the school environment means that first aid measures are instituted as early as possible, minimizing complications and possible sequelae to the victims, making these environments safer.

Being a study of the type before and after, it must be considered that the occurrence of a more significant score in the first stage of the knowledge that the professionals presented is due to the fact that they bring with them some knowledge constructed from the common sense, acquired through the interaction with the environment, where the subject incorporates experiences in the interpretation, getting closer to reality ${ }^{(7-8)}$.

The results of this study indicated that there was a significant improvement immediately after the course / training, due to the fact that there is the capacity to acquire theoretical and practical knowledge associated to new information and its applicability in potential situations that can be experienced in the school environment ${ }^{(2,6-7)}$.

These trainings should be permanent, where the contents must be presented visually with practical demonstrations, simulation of attendances and construction of scenarios close to the real situations where the subjects actively participate, and the psychomotor goals of learning are directed towards the acquisition of skills in these trainings, of knowledge levels of the subjects are not evaluated only in cognitive terms, but also in the levels of skills in first aid id-2,6-7). $^{(1)}$

In the sample obtained in this study, professionals were young and $71.4 \%$ (25) stated that they had already witnessed an emergency situation, a fact that was also verified in a study that evaluated the knowledge of 284 physical education teachers in first aid, $57.7 \%$ of males, with an average age of $37.6 \pm 7.1$ years, showed that $19.0 \%$ of the teachers interviewed had a good level of knowledge in emergency situations, and $50.5 \%$ presented insufficient performance to act in emergency situations, emphasizing that these 
professionals in the school environment need to have specific and continuous training with health professionals to be qualified in emergencies in schools ${ }^{(13)}$.

Circumstances requiring medical attention are common in schools. Teachers are often the first persons to witness medical emergencies with children in the school environment and this study aimed at determining the awareness, attitudes and practices of first aid teachers, assessed 146 professionals in nine schools in India using a self-administered questionnaire pointed out that only $69(47.0 \%)$ of the teachers had already received first aid training with insufficient knowledge, only eight knew the correct procedures and 96 (66.0\%) were willing to administer first aid if they received the necessary training ${ }^{(14)}$.

In a study of 110 preschool teachers, the average score of the knowledge was $11.9 \pm 2.9$ for 20 points, and did not present a significant difference in terms of age, work period, previous training and experience of a situation that needed ( $p>0.05)$, identifying that teachers did not have enough knowledge, this fact was also verified in this study where the performance of these professionals before the theoretical-practical course was also insufficient ${ }^{(1)}$.

In a study carried out with the application of a questionnaire to evaluate theoretical knowledge and a simulated scenario to evaluate practical skills in first aid, 30 teachers participated in grade school education, resulting that $60.0 \%$ of them presenting inadequate knowledge and in practice all ignore the management of the airways, $90.0 \%$ were unable to place in deposition of recovering and $60.0 \%$ did not provide clear information for the emergency call, as well as insufficient knowledge and skills, and there was a need to offer permanent courses ${ }^{(15)}$.

The performance of the professionals of this study was above $90.0 \%$ immediately after the theoretical-practical course, being verified in a study with 1067 teachers who received training in first aid, an average of 21 correct answers for 37 questions, while in the post-test, the average score increased to 32.2 $(\mathrm{p}<0.001)$ and $82.8 \%$ of the participants had a passing grade higher than $80.0 \%$ after the course ${ }^{(16)}$.

Trained health professionals have the responsibility for the teaching-learning process of lay people in emergency care, as there is the involvement of a complexity of actions, which aims at the development of the learner, in the cognitive as well as in the psychomotor and affective area, making clear the need to establish in these institutions a training program on first aid for lay people offering periodic training ${ }^{(3-7)}$.

\section{Conclusion}

It is concluded that the training is effective, with a significant increase in the percentage of correct answers after the course, with a performance of professionals over $90.0 \%$ in the assessment of skills and knowledge in first aid in the school environment.

\section{Acknowledgments}

The Institutional Program of Scientific and Technological Initiation Scholarships of the State University of Campinas, financed by the National Council of Scientific and Technological Development, and to all the participants of this study.

\section{Collaborations}

Calandrim LF, Santos AB and Oliveira LR contributed in the conception, collection, organization and interpretation of the data. Massaro LG contributed in writing and critically relevant analysis of the content. Vedovato CA and Boaventura AP contributed to the writing of the article and final approval of the version to be published. 


\section{References}

1. Sönmez Y, Uskun E, Pehlivan A. Knowledge levels of pre-school teachers related with basic firstaid practices, isparta sample. Turk Pediatri Ars. [Internet]. 2014 [cited 2017 Abr 14]; 49(3):23846. Available from: https://www.ncbi.nlm.nih. gov/pubmed/26078669

2. Slabe D, Fink R, Dolenc E, Kvas A. Knowledge of health principles among professionals in Slovenian kindergartens. Zdr Varst [Internet]. 2016 [cited 2017 Abr 14]; 55(3):185-94. Available from: https://www-ncbi-nlm-nih-gov.ez88.periodicos. capes.gov.br/pmc/articles/PMC5031068/pdf/ sjph-2016-0024.pdf

3. Martin AR. Educación para la salud en primeros auxilios dirigida al personal docente del ámbito escolar. Enferm Univ [Internet]. 2015 [citado 2016 Nov. 21]; 12(2):88-92. Disponible en: http://www.scielo.org.mx/scielo.php?script=sci_ arttext\&pid=S1665-70632015000200088

4. Nichiushi T, Hayashino Y, Iwami T, Kitamura T, Nishiyama C, Kajino K, et al. Epidemilological characteristic of sudden cardiac arrest in schools. Resuscitation [Internet]. 2014 [cited 2016 Aug. 3]; 85(8):1001-6. Available from: https://www.ncbi. nlm.nih.gov/pubmed/24820224

5. Perin EMF, Ferraboli SF, Kessler M, Moretti CA, Ribeiro MC, Silva OM, et al. Capacitação de primeiros socorros para leigos: a universidade perto da comunidade. UDESC Ação [Internet]. 2013 [citado 2016 Jun. 17]; 7(1);1-8. Disponível em: http://www.periodicos.udesc.br/index.php/ udescemacao/article/view/3169/pdf_22

6. Boaventura AP, Miyadahira AMK. Programa de capacitação em ressuscitação cardiorrespiratória com uso do desfibrilador externo automático em uma universidade. Rev Gaúcha Enferm [Internet]. 2012 [citado 2016 Jun. 16]; 33(1):191-4. Disponível em: http://www.scielo.br/pdf/rgenf/ v33n1/a25v33n1.pdf
7. Kawakame PMG, Miyadahira AMK. Assessment of the teaching-learning process in students of the health area: cardiopulmonary resuscitation maneuvers. Rev Esc Enferm USP [Internet]. 2015 [cited 2017 Apr 14]; 49(4):652-8. Available from: http://www.scielo.br/pdf/reeusp/v49n4/00806234-reeusp-49-04-0657.pdf

8. Magill RA. Aprendizagem motora: conceitos e aplicações. São Paulo: Edgard Blücher; 2002.

9. Hazinski MF, Nolan JP, Aickin R, Bhanji F, Billi JE, Callaway CW, et al. Part 1: executive summary: 2015 international consensus on cardiopulmonary resuscitation and emergency cardiovascular care science with treatment recommendations. Circulation [Internet]. 2015 [cited 2016 Oct 13];132 Suppl 1:2-39. Available from: http://circ. ahajournals.org/content/132/16_suppl_1/S2

10. Travers AH, Perkins GD, Berg RA, Castren M, Considine J, Escalante R, et al. Part 3: adult basic life support and automated external defibrillation: 2015 international consensus on cardiopulmonary resuscitation and emergency cardiovascular care science with treatment recommendations. Circulation. [Internet]. 2015 [cited 2016 Oct 13];132(Suppl):1-83. Available from: http://circ. ahajournals.org/content/132/16_suppl_1.toc

11. Böttiger BW, Aken HV. Kids save lives - training school children in cardiopulmonary resuscitation worldwide is now endorsed by the world health organization (WHO). Resuscitation. 2015; 94:5-7. doi: 10.1016/j.resuscitation.2015.07.005

12. Johnson RA, Wichern DW. The Bonferroni Method of multiple comparison. In: Johnson RA, Wichern DW. Applied multivariate statistical analysis. New York: Prentice-Hall International Inc; 1992. p.1979.

13. Esteves D, Pinheiro P, Brás R, O’Hara K, Rodrigues R. Avaliação do conhecimento dos professores de educação física para reagirem a situações de emergência. Motricidade [Internet]. 2015 [citado 2017 abr 14]; 11(1):39-53. Disponível em: http://revistas.rcaap.pt/motricidade/article/ view/3125/5153 
14. Joseph N, Narayanan T, Bin Zakaria S, Nair AV, Belayutham L, Subramanian AM, Gopakumar KG. Awareness, attitudes and practices of first aid among school teachers in Mangalore, south India. J Prim Health Care [Internet]. 2015 [cited 2017 Apr 14]; 7(4):274-81. Available from: https:// www.ncbi.nlm.nih.gov/pubmed/26668832

15. Adrien N, Onesphore H. Evaluation of first aid knowledge among elementary school teacher in Burundi. Int J Sports Sci Fitness [Internet]. 2015 [cited 2017 Apr 14]; 5(2):304. Available from: https://www.ijssf.org/PDF/v05issue02abs13.pdf
16. Feng L, Xiaoyang S, Jinsong Z, Fan J, Xiaoming S. Effects of pediatric first aid training on preschool teachers: a longitudinal cohort study in China. BMC Pediatr [Internet]. 2014 [cited 2017 Apr 14]; 14(1):209-17. Available from: https://bmcpediatr.biomedcentral.com/ articles/10.1186/1471-2431-14-209 